\title{
Pd(II) or Pt(II)-Catalyzed Hydroarylation of Alkynes by Arenes
}

\author{
Chengguo Jia, Tsugio Kitamura, and Yuzo Fujiwara* \\ Faculty of Engineering, Kyushu University,
}

Received April 17, 2001

\begin{abstract}
Efficient inter- and intramolecular hydroarylations of $\mathrm{C}-\mathrm{C}$ triple bonds by simple electron-rich arenes have been realized in the presence of $\mathrm{Pd}($ II $)$ or $\mathrm{Pt}$ (II ) catalysts and an acid such as trifluoroacetic acid and acetic acid. The reaction of heteroarenes such as pyrroles and indoles occurs under very mild conditions (e.g. at room temperature in neutral solvents such as $\mathrm{CH}_{2} \mathrm{Cl}_{2}$ ). The reaction provides a very good strategy for functionalization of arenes as well as heteroarenes, affording arylalkenes. The intramolecular reaction offers a concise and straightforward route to biologically interesting heterocycles such as coumarins, quinolinones and thiocoumarins. The possible mechanism involving electrophilic metalation of aromatic $\mathrm{C}-\mathrm{H}$ bonds by a cationic metallic species such as $\left[\mathrm{Pd}\left(\mathrm{O}_{2} \mathrm{CCF}_{3}\right)\right]^{+}$and the formation of a vinyl cationic species is discussed.
\end{abstract}

\section{Introduction}

Catalytic addition reaction is regarded as one of most atom economical reactions in synthesis. ${ }^{1}$ Catalytic activation of aromatic $\mathrm{C}-\mathrm{H}$ bonds leading to useful addition or coupling reactions with new $\mathrm{C}-\mathrm{C}$ bond formation is of considerable interest for the chemical and pharmaceutical industries, and remains a challenge to chemists, ${ }^{2}$ because it would provide simple and economical methods for producing aryl-substituted compounds directly from simple arenes and no prefunctionalization like halogenation is involved.

The study of the reactivity of aryl $\mathrm{C}-\mathrm{H}$ bonds in the presence of transition metal compounds began around the 1960s despite the quite early discovery of Friedel-Crafts alkylation and acylation reactions with Lewis acid catalysts. In 1967, we reported $\mathrm{Pd}$ ( II )-mediated coupling reaction of arenes with olefins in refluxing $\mathrm{AcOH} .{ }^{3}$ The reaction involves the electrophilic substitution of aromatic $\mathrm{C}-\mathrm{H}$ bonds by a $\mathrm{Pd}$ (II) species (Scheme1), ${ }^{3 \mathrm{c}}$ and this may be one of the earliest examples of aromatic $\mathrm{C}-\mathrm{H}$ bond activation by transition metal compounds. Although there are many examples of stoichiometric reaction of aromatic $\mathrm{C}-\mathrm{H}$ bonds with transition metal compounds, ${ }^{1}$ few catalytic systems are available for synthetic purposes. The direct use of aromatic compounds in synthesis is generally restricted to the activation of groups other than the $\mathrm{C}-\mathrm{H}$ bonds (e. g., $\mathrm{C}-\mathrm{Br}, \mathrm{C}-\mathrm{Cl}$ bonds). ${ }^{4}$ However, the manufacture of aryl halides is not an environmentally friendly process, and thus the future of bulk synthesis of aryl derivatives may lie in the direct activation of $\mathrm{C}-\mathrm{H}$ bonds. Activation of aromatic $\mathrm{C}-\mathrm{H}$ bonds by ortho-chelating assisted oxidative addition to low-valent transition metal compounds, leading to addition to $\mathrm{C}-\mathrm{C}$ multiple bonds, has been recognized as another promising route. ${ }^{2 b}$

In our attempt to extend the coupling reaction of arenes with alkenes to alkynes, it was found that the reaction of arenes with ethyl propiolate gave addition products instead of coupling products in TFA (trifluoroacetic acid) (Scheme 2). ${ }^{5}$ This addition reaction has been extended to various alkynes and various arenes and also to intramolecular reactions for preparation of heterocycles such as coumarins, quinolinones, and thiocoumarins.

Scheme 1. The reaction aryl-Pd complexes

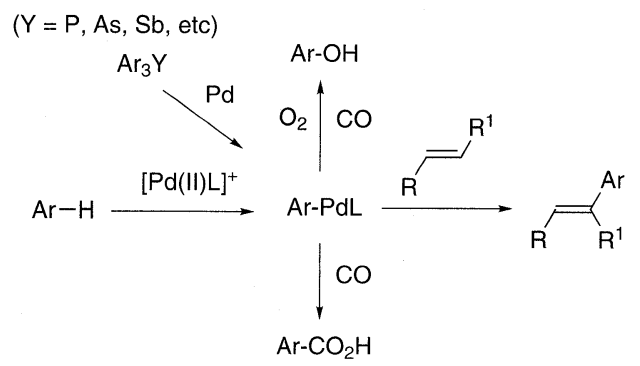

Scheme 2. Pd-Catalyzed reaction of 1,4-dimethoxybenzene with ethyl propiolate in TFA

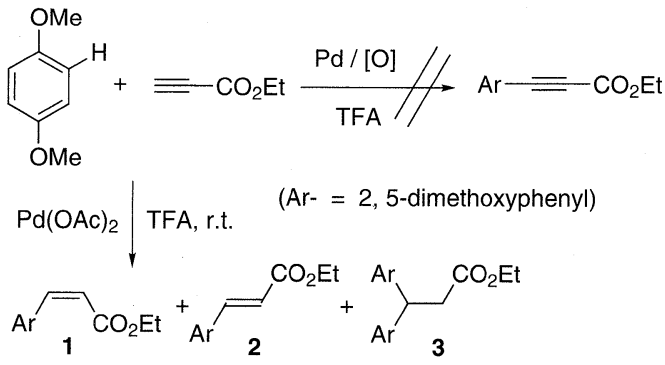

\section{Intermolecular Hydroarylation of Alkynes by Arenes}

\subsection{The Reaction of Benzenoid Arenes}

In the course of our studies of oxidative coupling of arenes with olefins, the possibility to extend the coupling reaction to terminal alkynes was investigated by the reaction of $p$-dimethoxybenzene with ethyl propiolate in the presence of an oxidant and a catalytic amount of $\mathrm{Pd}(\mathrm{OAc})_{2}$ in TFA. Instead of the expected coupling product, ethyl 3-(2, 5 -dimethoxyphenyl) propiolate, the reaction gave ethyl $(2 Z)$ -3-(2,5-dimethoxyphenyl)-2-propenoate (1) $\left(J_{\mathrm{H}-\mathrm{H}}=12.3\right.$ 
$\mathrm{Hz})$ as the main product, together with small amounts of the corresponding $E$-isomer $(2)\left(J_{\mathrm{H}-\mathrm{H}}=16.2 \mathrm{~Hz}\right)$ and an arene/ alkyne 2/1 adduct, ethyl 3,3-bis (2,5-dimethoxyphenyl) propionate (3). ${ }^{5 \mathrm{~b}}$ Apparently, the compounds 1 and $\mathbf{2}(1 / 1$ adducts) resulted from mono-addition of the arene to the alkyne, and 3 resulted from subsequent addition of another molecular arene to compound $\mathbf{2}$ (or $\mathbf{1}$ ). This has been confirmed by the addition reaction of arenes to alkenes. The addition reaction proceeds smoothly regardless of whether oxidants such as $t-\mathrm{BuOOH}$ and benzoquinone were employed or not. However, the reaction did not occur without either TFA or $\mathrm{Pd}(\mathrm{OAc})_{2}$.

Table 1. Effect of Pd catalysts on the reaction of 1,4-dimethoxybenzene with ethyl propiolate in TFA ${ }^{\mathrm{a}}$

\begin{tabular}{|c|c|c|c|c|c|}
\hline \multirow{2}{*}{ Entry } & \multirow{2}{*}{ Catalyst ( $\mathrm{mol} \%$ ) } & \multirow{2}{*}{ Time $(h)$} & \multicolumn{3}{|c|}{ Yield $(\%)^{b}$} \\
\hline & & & 1 & 2 & 3 \\
\hline $1 \mathrm{~F}$ & $\mathrm{Pd}(\mathrm{OAc})_{2},(0.1)$ & 180 & 68 & 4 & 7 \\
\hline $2 F$ & $\mathrm{Pd}(\mathrm{OAc})_{2},(1)$ & 45 & $72(56)$ & 6 & 5 \\
\hline $3 \mathrm{~F}$ & $\mathrm{Pd}(\mathrm{OAc})_{2},(5)$ & 27 & 26 & 15 & 2 \\
\hline $4 \mathrm{~F}$ & $\mathrm{Pd}(\mathrm{OAc})_{2},(5)$ & 70 & $<3$ & 5 & (31) \\
\hline $5 F$ & $\mathrm{Pd}(\mathrm{OAc})_{2}(1)^{c}$ & 48 & 58 & 3 & 3 \\
\hline $6 \mathrm{~F}$ & $\begin{array}{l}\mathrm{Pd}(\mathrm{OAc})_{2},(1)+ \\
\mathrm{P}\left[\mathrm{C}_{6} \mathrm{H}_{3}(\mathrm{OMe})_{2}\right]_{3},(1)\end{array}$ & 45 & 70 & 5 & 6 \\
\hline $7 \mathrm{~F}$ & $\mathrm{Pd}(\mathrm{OAc})_{2}(1)+\mathrm{PPh}_{4}(4)$ & 45 & 41 & $\operatorname{trac}$ & \\
\hline $8 \mathrm{~F}$ & $\mathrm{Pd}\left(\mathrm{PPh}_{3}\right)_{4}(2)$ & 48 & 5 & $\operatorname{tra}$ & \\
\hline 9 & Pd (5\%) / Carbon (5) & 48 & 8 & tra & \\
\hline $10 F$ & $\mathrm{Pd}(\mathrm{acac})_{2}$ & 48 & 68 & 3 & 2 \\
\hline 11 & $\mathrm{PdCl}_{2}$ (1) & 48 & 36 & 3 & $<1$ \\
\hline 12 & $\mathrm{Pd}\left(\mathrm{O}_{2} \mathrm{CCF}_{3}\right)_{2}\left(\mathrm{PPh}_{3}\right)_{2}$ & 48 & 69 & 5 & 6 \\
\hline 13 & $\mathrm{Pd}\left(\mathrm{O}_{2} \mathrm{CCF}_{3}\right)_{2}\left(\mathrm{PPh}_{3}\right)_{2},(1)^{d}$ & 48 & $<3$ & $\operatorname{trac}$ & \\
\hline 14 & $\mathrm{PdCl}_{2}(1)+\mathrm{AgO}_{3} \mathrm{SCF}_{3}(2)^{e}$ & 48 & 10 & trac & \\
\hline 15 & no catalyst & 60 & no rec & actic & \\
\hline
\end{tabular}

a Reaction conditions: $p$-dimethoxybenzene $(30 \mathrm{mmol})$, ethy propiolate $(5 \mathrm{mmol})$, TFA ( $4 \mathrm{~mL})$, r. t. ${ }^{b} \mathrm{GC}$ yield (yields in parenthesis refer to isolated yields) based on the alkyne. ${ }^{c} 10$ mmol of the arene employed. ${ }^{d} \mathrm{AcOH}(4 \mathrm{~mL})+\mathrm{TFA}(0.5 \mathrm{~mL})$ used as the solvent and $\mathrm{CF}_{3} \mathrm{CO}_{2} \mathrm{Na}(0.025 \mathrm{mmol})$ added. ${ }^{\theta}$ $\mathrm{CH}_{2} \mathrm{Cl}_{2}(4 \mathrm{~mL})+\mathrm{CF}_{3} \mathrm{SO}_{3} \mathrm{H}(0.5 \mathrm{~mL})$ used as a solvent.

Prior to surveying the scope of this addition reaction, the reaction conditions were optimized and the results are listed in Table 1. $\mathrm{Pd}(\mathrm{II})$ catalysts such as $\mathrm{Pd}(\mathrm{OAc})_{2}, \mathrm{Pd}\left(\mathrm{O}_{2} \mathrm{CCF}_{3}\right)_{2}$ $\left(\mathrm{PPh}_{3}\right)_{2}$, and $\mathrm{Pd}(\mathrm{acac})_{2}$ showed higher catalytic activity than $\mathrm{Pd}(0)$ catalysts such as $\mathrm{Pd} /$ Carbon and $\mathrm{Pd}\left(\mathrm{PPh}_{3}\right)_{4}$ (see entries $2,10,12,8,9$ in Table 1). The reaction was enhanced greatly by increasing the amount of $\mathrm{Pd}(\mathrm{OAc})_{2}$ (from $0.1 \%$ to $1 \%$, entries 1 and 2 in Table 1). When it was increased to $5 \%$, the $2 / 1$ adduct 3 was obtained as the main product (entry 4 in Table 1). This means whether the reaction gives $1 / 1$ or $2 / 1$ adducts as the main product can be controlled by the concentration of $\mathrm{Pd}(\mathrm{OAc})_{2}$. Higher concentration of $\mathrm{Pd}(\mathrm{II})$ facilitates the overall reaction. The tris $(2,6$-dimethoxyphenyl) phosphine was added( 1 equiv. to Pd, entry 6 in Table 1) to the system in order to improve the addition reaction, ${ }^{4,5 b}$ but was found to have very little effect. However, adding more phosphine (4 equiv. to Pd, entry 7 in Table 1) decreased the catalytic activity of the system presumably because of blocking of the coordination sites of $\mathrm{Pd}(\mathrm{II})$. The best results were obtained with $\mathrm{Pd}(\mathrm{OAc})_{2}$ /TFA and $\mathrm{Pd}\left(\mathrm{O}_{2} \mathrm{CCF}_{3}\right)_{2}$ $\left(\mathrm{PPh}_{3}\right)_{2} /$ TFA systems (entries 2 and 12 in Table 1). Attempts to reduce the amount of TFA used in the reaction or to use another $\mathrm{Pd}$ ( II ) cationic system such as $\mathrm{PdCl}_{2} / \mathrm{CF}_{3} \mathrm{SO}_{3} \mathrm{Ag}$ only resulted in low yields(entries 13 and 14 in Table 1).

The scope and generality of this reaction were explored first using various commercially available arenes and acetylenes (Tables 2 and 3). The addition of the arenes to ethyl propiolate gave cis-adducts, ethyl (2Z)-3-aryl-2propenoates $\left(J_{\mathrm{H}-\mathrm{H}}=11.7 \pm 0.6 \mathrm{~Hz}\right)$, predominantly in most cases (entries $1-15$ in Table 2). The corresponding trans-isomers as the minor product were isolated (entry 15 in Table 2) or identified in the mixture of adducts by ${ }^{1} \mathrm{H} \mathrm{NMR}\left(J_{\mathrm{H}-\mathrm{H}}=\right.$ $15.9-16.5 \mathrm{~Hz}$ ) in some cases (entries 4 and 14 in Table 2). Arene/alkyne $1 / 2$ adducts, $(2 E, 4 Z)-4$-(ethoxycarbonyl)5-aryl-2, 4-pentadienoates, as the minor products were observed in the reaction(e.g., entries 1, 6-9 in Table 2), and also arene/alkyne 2/1 adducts, ethyl 3-bisarylpropionates, were found to be the main products in some cases(entries 14 and 16 in Table 2).

The reaction exhibited very good chemoselectivity with unprotected $\mathrm{OH}$ and $\mathrm{Br}$ substituents in arenes, all proving to be compatible (entries 10-13 in Table 2). A coumarin was obtained from the reaction of $p-t$-butylphenol with ethyl propiolate(entries 10 and 11 in Table 2), apparently resulting from the first addition of the phenol to the alkyne followed by cyclization via ester exchange (Scheme 3 ). When the ortho-positions of a phenol were occupied by two methyl groups, the reactions gave a $1 / 1$ adduct (entry 12 in Table 2). The reaction of mesityl bromide with ethyl propiolate afforded 1/1 adduct, ethyl(2Z)-3-(2,4, 6-trimethyl-3-bromophenyl)-2-propenoate(entry 13 in Table 2). No corresponding debrominated adduct or debrominated arene was isolated or observed by ${ }^{1} \mathrm{H}$ NMR from the reaction mixture, suggesting that the catalytic cycle may not involve the $\operatorname{Pd}(0)$ species.

Scheme 3. The formation of coumarins from the reaction of phenol with alkynoates or alkynoic acids

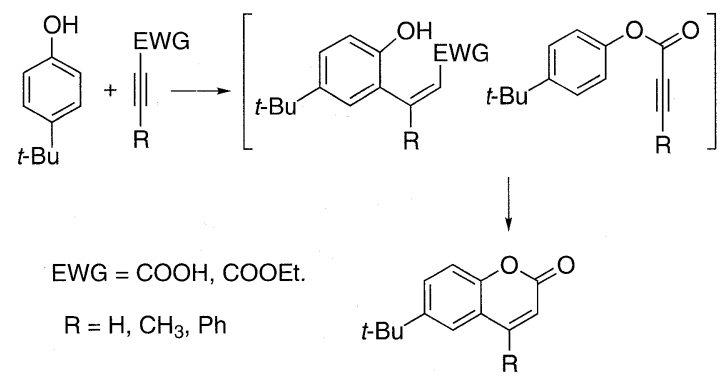

A diene, ethyl (2Z)-3-\{2,4,6-trimethyl-3-[(Z)-2-ethoxycarbonylethylenyl)] phenyl] \} propenoate, was obtained from the reaction of ethyl(2Z)-3-mesitylpropenoate with 1.5 equiv. of ethyl propiolate (entry 5 in Table 2) or directly from the reaction of mesitylene with ethyl propiolate(entry 8 in Table 2 ). This provides a new and simple way to aryldienes from simple arenes and alkynes, and similar compounds would be prepared from diiodoarenes by the Heck reaction. ${ }^{6}$

The internal alkynes that bear functional groups such as $\mathrm{CHO}, \mathrm{COMe}$ and $\mathrm{CO}_{2} \mathrm{H}$ proved to be compatible to the reaction (see Table 3 ). The reaction affords thermodynamically unfavorable $c i s$-arylalkenes predominantly in most cases (entries 3-17, 19-26 in Table 3), giving good yields of adducts especially in the $\mathrm{PtCl}_{2} / 2 \mathrm{AgOAc}$ system.

Inspired by the higher selectivity of the $\mathrm{PtCl}_{2} / 2 \mathrm{AgOAc}$ sys- 
Table 2. Pd and Pt-catalyzed addition of arenes to ethyl propiolate ${ }^{\mathrm{a}}$

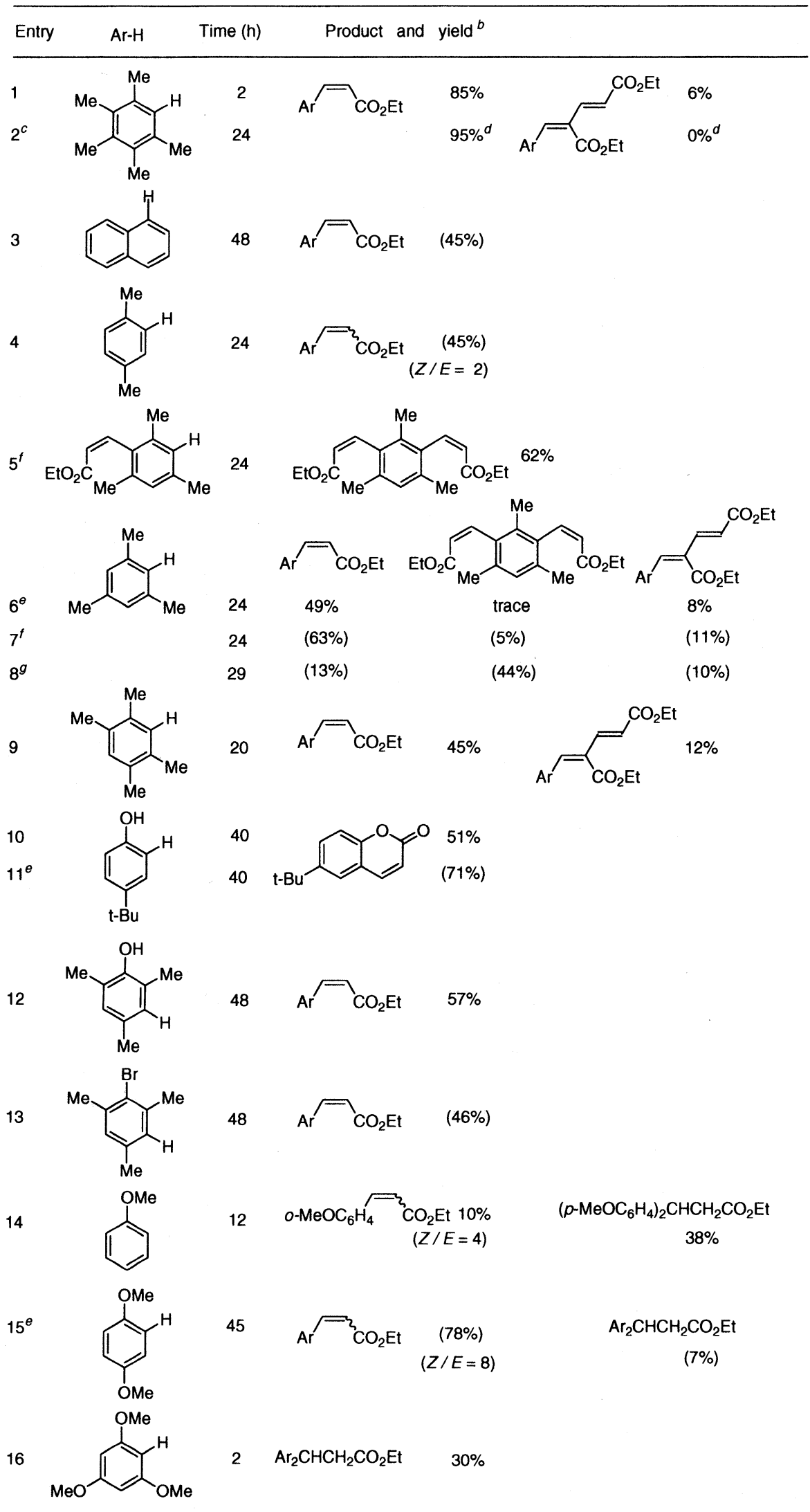

a General conditions: arene (10 mmol), ethyl propiolate $(5 \mathrm{mmol}), \mathrm{Pd}(\mathrm{OAc})_{2}(0.05 \mathrm{mmol}), \mathrm{TFA}(4 \mathrm{~mL})$ and $\mathrm{CH}_{2} \mathrm{Cl}_{2}(1 \mathrm{~mL})$ at r.t. ${ }^{\mathrm{b}}$ Isolated yield (GC yield in parenthesis) based on the acetylene. ${ }^{\mathrm{C}} \mathrm{PtCl}_{2}(0.25$ mmol) + AgOAc (0.5 mmol) used as catalyst. ${ }^{d}$ Yield determined by ${ }^{1} \mathrm{H}$ NMR spectrum. ${ }^{e}$ Arene (30 mmol) added. 'Arene $(3.4 \mathrm{mmol})$ and alkyne $(5 \mathrm{mmol})$ used, and the yield based on the arene. ${ }^{9}$ Arene $(3.4 \mathrm{mmol})$ and alkyne $(10 \mathrm{mmol})$ used, and the yield based on the arene. 
Table 3. Transition metal-catalyzed addition of arenes to internal alkynes

$$
\mathrm{Ar}-\mathrm{H}+\mathrm{R}^{1}=\mathrm{R}^{2} \frac{\mathrm{Pd}(\mathrm{II}) \text { or Pt(II) }}{\mathrm{TFA} / \mathrm{CH}_{2} \mathrm{Cl}_{2} \text {, r.t. }} \underset{\mathrm{Ar}}{\mathrm{Rr}_{1}^{1}} \overbrace{\mathrm{R}^{2}}
$$

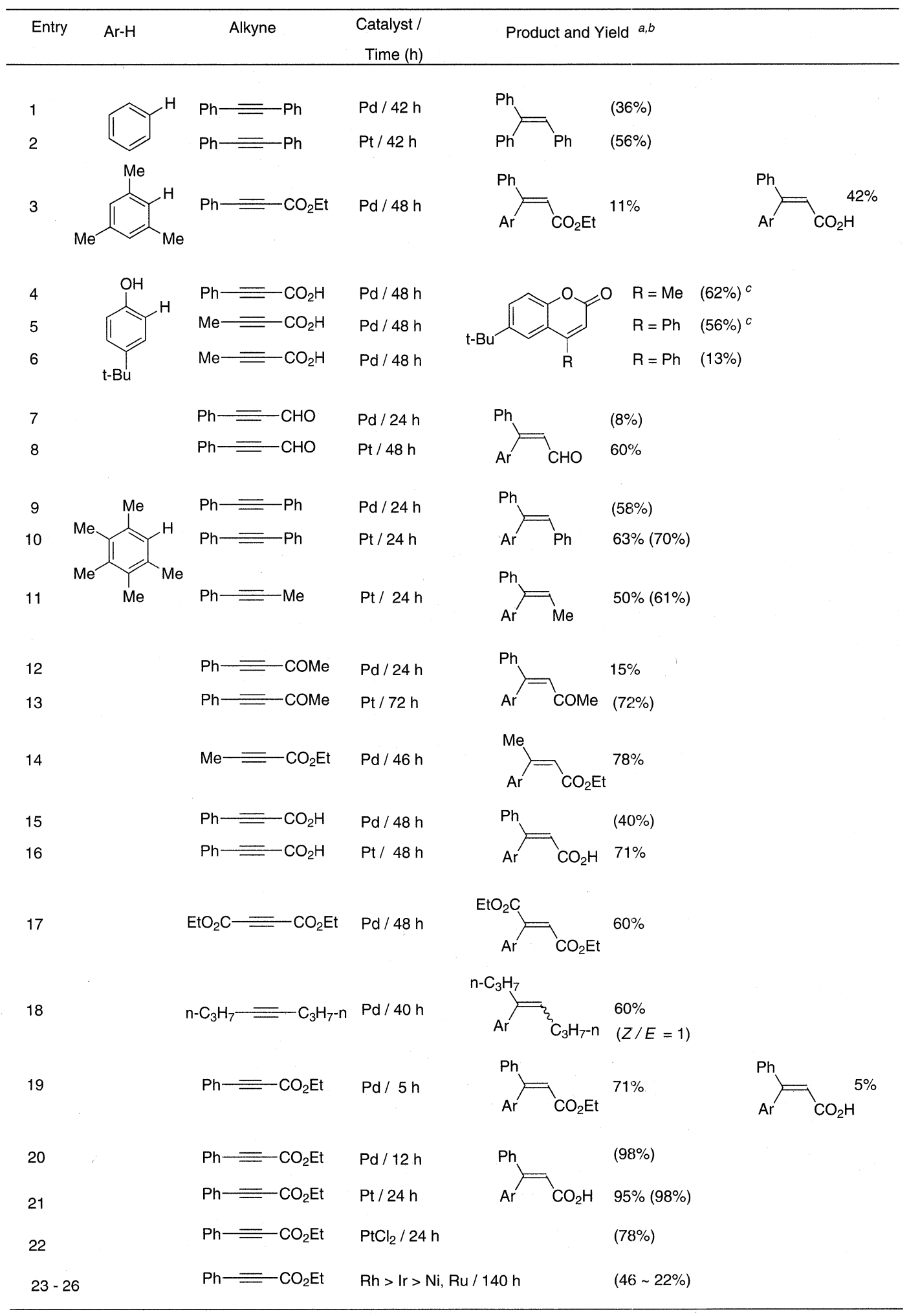

a General conditions: arene (10 mmol), alkyne (5 mmol), TFA (4 mL), $\mathrm{CH}_{2} \mathrm{Cl}_{2}(1 \mathrm{~mL})$, r.t. Pd, Pt, Rh, Ir, Ni, and $\mathrm{Ru}$ refer to $\mathrm{Pd}(\mathrm{OAc})_{2}, \mathrm{PtCl}_{2} / 2 \mathrm{AgOAc}, \mathrm{Rh}_{2}(\mathrm{OAc})_{4}, \mathrm{IrCl}_{3} / 3 \mathrm{AgOAc}, \mathrm{Ni}(\mathrm{OAc})_{2}$, and $\mathrm{RuCl}_{3} / 3 \mathrm{AgOAc}$, respectively. ${ }^{\mathrm{b}}$ Isolated yield (GC yield in parenthesis) based on the alkyne. ${ }^{C}$ Trifluoroacetic anhydride $(5 \mathrm{mmol})$ was added. 
tem(entries 1 and 2 of Table 2), several other transition metals such as $\mathrm{Rh}$ (III), $\operatorname{Ir}$ (III), $\mathrm{Ru}$ (III) and $\mathrm{Ni}$ (II) were tested in the reaction of pentamethylbenzene with ethyl phenylpropiolate in order to screen the catalytic systems by comparison with the $\mathrm{Pd}$ ( II ) and $\mathrm{Pt}$ ( II ) systems (entries 19-26 in Table 3). Ethyl (2Z)-3-(pentamethylphenyl)cinnamate and the corresponding hydrolyzed (2Z)-3-(Pentamethylphenyl)cinnamic acid were isolated upon usual work-up (entry 19 in Table 3). The results summarized in Table 3 indicate that $\mathrm{Pd}(\mathrm{OAc})_{2}$ and $\mathrm{PtCl}_{2} / \mathrm{AgOAc}$ as catalysts are superior to other transition metal systems (entries $19-26$ in Table 3). $\mathrm{Pd}(\mathrm{OAc})_{2}$ has been found to be the most active catalyst. The reaction with $\mathrm{PtCl}_{2} / \mathrm{AgOAc}$ was slower (lower conversion of alkynes) than that with $\mathrm{Pd}(\mathrm{OAc})_{2}$ (entries 20 and 21 in Table 3), but gave higher yields at the same conversion level(entries 7-16 in Table 3 ). The catalytic activity of the transition metals decreases in the order: $\operatorname{Pd}($ II $)>\operatorname{Pt}($ II $)>\operatorname{Rh}($ III $)>\operatorname{Ir}($ III $)>$ $\mathrm{Ni}(\mathrm{II}), \mathrm{Ru}(\mathrm{II})$, in accordance with the activity difference in electrophilic metalation of aromatic $\mathrm{C}-\mathrm{H}$ bonds by these metal ions. ${ }^{2 a}$

The regio- and stereochemistry of all adducts (in Tables 2 and 3) was unambiguously established on the basis of chemical shifts and coupling constants in the ${ }^{1} \mathrm{H}$ NMR spectra, and differential NOE experiments. The structures of 1(pentamethylphenyl)-1-phenyl-2-phenylethylene and 1-(pentamethylphenyl)-1-phenylpropene were further confirmed to be $(Z)$-configuration by the $\mathrm{X}$-ray crystal structure.

A close examination of all the results listed in Tables 2 and 3 reveals that the nature of the substituents in alkyne has a considerable effect on the regiochemistry of the reaction products and also on the reactivity of alkynes. The alkynes conjugated to an electron-withdrawing group such as $\mathrm{CHO}$, $\mathrm{CO}_{2} \mathrm{H}$, COMe or $\mathrm{CO}_{2} \mathrm{Et}$ act as good acceptors of aryl nucleophiles, providing $\beta$-aryl substituted alkenes exclusively and being $c i s-a l k e n e s$ predominantly in most cases. The regiochemistry of this reaction is dominated by electronic effects of the substituents in alkyne rather than steric effects, similarly to the effect of the substituents in arenes. The reaction with internal alkynes is slower than that with terminal alkynes. For instance, the reactivity of acetylenes $\mathrm{RC} \equiv$ $\mathrm{CCO}_{2}$ Et decreases with the substituent $\mathrm{R}$ in the order: $(\mathrm{R}=)$ $\mathrm{H}>\mathrm{Ph}>\mathrm{Me}$.

A possible side reaction is the addition of trifluoroacetic acid to the $\mathrm{C}-\mathrm{C}$ triple bonds of alkynes followed by hydrolysis to give ketones. This has been also observed in a few cases under our reaction conditions, especially in the absence of the arene or in the presence of inactive arenes, while in the absence of the Pd catalyst no such side reaction occurs.

\subsection{The Reaction of Heteroarenes}

The reaction of heteroarenes with alkynoates occurs under very mild conditions. ${ }^{5 \mathrm{~d}}$ Initially, the effects of catalysts and solvents on the reaction of pyrrole with ethyl phenylpropiolate were investigated and the results are shown in Table 4. With $\mathrm{Ni}(\mathrm{OAc})_{2}$ or $\mathrm{Cu}(\mathrm{OAc})_{2}$ as the catalyst or without the transition metal catalysts(entries $1-3$ in Table 4), no reaction product was detected by the GC method. Ethyl $(Z)-3-$ (2-pyrryl)phenylpropenoate was obtained in $76 \%$ yield as the only isolated product in the presence of $5 \mathrm{~mol} \% \mathrm{Pd}(\mathrm{OAc})_{2}$ in $\mathrm{AcOH}$ in $2 \mathrm{~h}$ (entry 5 in Table 4). The configuration of the adduct was unambiguously established by ${ }^{1} \mathrm{H}$ nuclear Overhauser effect(NOE) experiments. The catalyst of $\mathrm{PtCl}_{2}$ was much less active than $\mathrm{Pd}(\mathrm{OAc})_{2}$, giving a low yield(entry 4 in Table 4). The rate of reaction was apparently reduced if less $\mathrm{Pd}(\mathrm{OAc})_{2}(1 \mathrm{~mol} \%)$ was used (entry 6 in Table 4$)$. Furthermore, it was found that this reaction could proceed without any solvent or in various solvents such as dichloromethane as well as water (entries 8-12 in Table 4). However, acetic acid is the best one among all solvents tested in the reaction.

Table 4. Effects of catalysts and solvents on the addition of pyrrole to ethyl phenylpropiolate

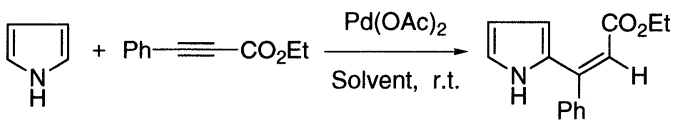

\begin{tabular}{|c|c|c|c|c|}
\hline \multicolumn{2}{|c|}{ Entry Catalyst (mol\%) } & \multirow{2}{*}{$\frac{\text { Solvent }}{\mathrm{AcOH}}$} & \multirow{2}{*}{$\begin{array}{c}\text { Time }(\mathrm{h}) \\
48\end{array}$} & \multirow{2}{*}{$\frac{\text { Yield (\%) }}{\text { None }}$} \\
\hline 1 & None & & & \\
\hline 2 & $\mathrm{Cu}(\mathrm{OAc})_{2}(5)$ & $\mathrm{AcOH}$ & 48 & None \\
\hline 3 & $\mathrm{Ni}(\mathrm{OAC})_{2}(5)$ & $\mathrm{AcOH}$ & 48 & None \\
\hline 4 & $\mathrm{PtCl}_{2}(5)$ & $\mathrm{AcOH}$ & 24 & 8 \\
\hline 5 & $\mathrm{Pd}(\mathrm{OAc})_{2}(5)$ & $\mathrm{AcOH}$ & 2 & $86(76$ \\
\hline 6 & $\mathrm{Pd}(\mathrm{OAc})_{2}(1)$ & $\mathrm{AcOH}$ & 8 & 91 \\
\hline 7 & $\mathrm{Pd}(\mathrm{OAC})_{2}(5)$ & $\mathrm{AcOH}$ & 2 & $60^{b}$ \\
\hline 8 & $\mathrm{Pd}(\mathrm{OAc})_{2}(5)$ & None & 24 & 91 \\
\hline 9 & $\mathrm{Pd}(\mathrm{OAc})_{2}(5)$ & $\mathrm{CH}_{2} \mathrm{Cl}_{2}$ & 48 & 40 \\
\hline 10 & $\mathrm{Pd}(\mathrm{OAC})_{2}(5)$ & Ether & 96 & 42 \\
\hline 11 & $\mathrm{Pd}(\mathrm{OAc})_{2}(5)$ & AcEt & 96 & 24 \\
\hline 12 & $\mathrm{Pd}(\mathrm{OAc})_{2}(5)$ & $\mathrm{H}_{2} \mathrm{O}^{\mathrm{c}}$ & 40 & 78 \\
\hline
\end{tabular}

${ }^{a}$ Isolated yield of adduct from the reaction of pyrrole ( 3 $\mathrm{mmol})$ with alkynoate $(1 \mathrm{mmol})$ in the presence of $\mathrm{Pd}(\mathrm{OAc})_{2}(5 \mathrm{~mol} \%)$ in a solvent $(1 \mathrm{~mL})$ at r.t. ${ }^{\mathrm{b}}$ Pyrrole (1 mmol), ethyl phenylpropiolate $(3 \mathrm{mmol}) .{ }^{c} \mathrm{H}_{2} \mathrm{O}(0.5$ $\mathrm{mL})$.

Heteroaromatic compounds such as pyrroles, furans and indoles readily undergo addition reaction with alkynoates at room temperature in the presence of a catalytic amount of $\mathrm{Pd}$ $(\mathrm{OAc})_{2}$ in acetic acid or $\mathrm{CH}_{2} \mathrm{Cl}_{2}$, affording cis-heteroarylalkenes in most cases(Table 5). This reaction provides a synthetic protocol to heteroarylalkenes, especially cis-alkenes, from simple heteroarenes. Various heteroarenes and alkynoates were tested in the present reaction at room temperature and the results are shown in Table 5. The reaction either gave mono-addition products, 3-arylpropenoates and in $Z$-configuration in most cases, or diaddition products, 3-diarylpropanoates, depending on the substituents $(\mathrm{R})$ of alkynoates and the solvent.

With small $\mathrm{R}$ groups such as $\mathrm{Me}$ or $n-\mathrm{C}_{5} \mathrm{H}_{11}$ in alkynoates, the reaction in $\mathrm{AcOH}$ mainly afforded diaddition products(entries 3, 4 and 18 in Table 5), while the reaction gave mono-addition products with a relatively bulky $\mathrm{R}$ group like $\mathrm{Ph}$ under the same conditions (entries 1 , and 10-16 in Table 5). It has been confirmed that the diaddition products were produced by further addition of heteroarenes to the arylalkenes in $\mathrm{AcOH}$. However, even with small $\mathrm{R}$ substituents such as $\mathrm{Me}$ and $\mathrm{H}$ in alkynoates, the reaction can be controlled to stop at the mono-addition step to give arylalkene when $\mathrm{CH}_{2} \mathrm{Cl}_{2}$ was used as the solvent(entries 2, 6 and 9 in Table 5), although the reactions in $\mathrm{CH}_{2} \mathrm{Cl}_{2}$ were slow.

For pyrrole, 1-methylpyrrole, 2-methylfuran, and 2, 3-dimethylfuran, the substitution of aromatic $\mathrm{C}-\mathrm{H}$ bonds occurs exclusively at the 2 or 5 -position of arenes(e.g. entries 
Table 5. Pd-catalyzed hydroarylation of alkynoates by hetero-aromatic compounds

$$
\begin{aligned}
& \mathrm{Ar}-\mathrm{H}+\mathrm{R}=\mathrm{CO}_{2} \mathrm{Et} \frac{\mathrm{Pd}(\mathrm{OAC})_{2}}{\mathrm{HOAC} \text { or } \mathrm{CH}_{2} \mathrm{Cl}_{2} \text {, r.t. }} \mathrm{Ar}_{\mathrm{Rr}}^{\mathrm{R}}=\mathrm{CO}_{2} \mathrm{Et} \\
& \stackrel{\mathrm{Ar}-\mathrm{H}}{\mathrm{HOAC}, \text { r.t. }} \mathrm{Ar} \underset{\mathrm{Ar}}{\mathrm{R}} \mathrm{CO}_{2} \mathrm{Et}
\end{aligned}
$$

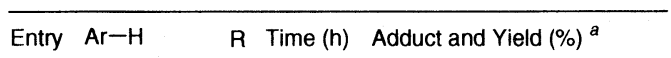

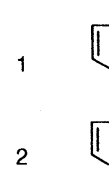

$\mathbb{H}_{\mathrm{H}} \boldsymbol{N}_{\mathrm{H}} \mathrm{Ph} \quad 2$

$\overbrace{\mathrm{H}} \mathrm{C}_{\mathrm{H}} \quad \mathrm{Me} 48$

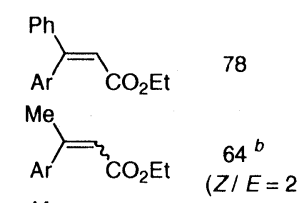

3<smiles>c1cc[nH]c1</smiles>

Me 24

$\stackrel{\mathrm{Ar}}{\mathrm{Me}} \mathrm{CO}_{2} \mathrm{Et} \quad 57$

4

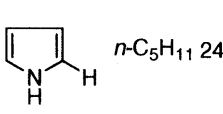

$\mathrm{nC}_{5} \mathrm{H}_{11} \quad \mathrm{nC}_{5} \mathrm{H}_{11}$

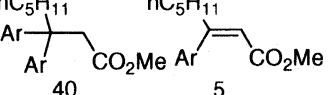

5

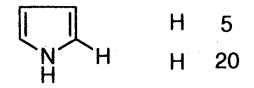

7

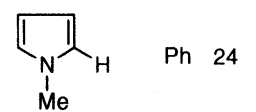

$\mathrm{Ar}^{\longrightarrow} \mathrm{CO}_{2} \mathrm{Et}$

$18^{b}$

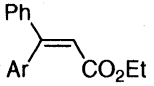

83 $\mathrm{Me}$<smiles>Cc1ccc([N+](=O)[O-])[nH]1</smiles>
Ph 20<smiles>CCOC(=O)/C=C(\[Al])c1ccccc1</smiles>

H 20

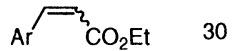

$(E / Z=1.3: 1)$

10<smiles>O=C([O-])c1cc([N+](=O)[O-])c([N+](=O)[O-])[nH]1</smiles>

$\mathrm{Ph}$ 6d

11<smiles>Cc1ccco1</smiles>
Ph 48

12

$13 \overbrace{\mathrm{Et}} \overbrace{\mathrm{H}} \mathrm{Ph} 48$

14<smiles>[R4]c1ccccc1[N+](=O)[O-]</smiles>

15<smiles>O=[N+]([O-])c1[nH]c2ccccc2c1[Pb]</smiles><smiles></smiles>
$\mathrm{Me}$

17<smiles>c1ccc2[nH]ccc2c1</smiles>

18<smiles>C1=CNc2ccccc2N1</smiles><smiles>CCOC(=O)/C=C(\[Al])c1ccccc1</smiles><smiles>CCOC(=CC(=[V])c1ccccc1)c1ccccc1</smiles><smiles>CCOC(=CC(=[Al])c1ccccc1)c1ccccc1</smiles><smiles>CCOC(=O)/C=C(\[Te])c1ccccc1</smiles><smiles>CCOC=C(C)c1ccccc1</smiles><smiles>CCOC(=O)/C=C(\[Al])c1ccccc1</smiles><smiles>CCOC(=O)/C=C(\[Te])c1ccccc1</smiles><smiles>CCOC(=O)/C=C(/[Al])c1ccccc1</smiles><smiles>CCOC(=O)CC(C)([Al])[Al]</smiles>

a Isolated yield from heteroarenes $(2 \mathrm{mmol})$ with alkynoates (1 $\mathrm{mmol})$ in $\mathrm{HOAC}(1 \mathrm{~mL})$ at r.t. ${ }^{\mathrm{b}} \mathrm{CH}_{2} \mathrm{Cl}_{2}(1 \mathrm{~mL})$ as the solvent. ${ }^{c}$ Ethyl propiolate $(3 \mathrm{mmol})$ and pyrrole $(1 \mathrm{mmol})$ were used, and $\mathrm{CH}_{2} \mathrm{Cl}_{2}$ (1 mL) was used as solvent. ${ }^{d}$ TFA $/ A C O H(1: 2)$ as the solvent
1, 7, 11 and 12 in Table 5), being characteristic of electrophilic substitution. For indole and 1-methylindole, the reaction occurred at the 3-position predominantly while very small amounts $(<3 \%)$ of 2 -substituted adducts could be detected by ${ }^{1} \mathrm{H}$ and ${ }^{13} \mathrm{C}$ NMR spectra. However, when the 2 , 5-positions of pyrrole and the 3-position of indole were occupied by the substituent(s), the reaction could proceed smoothly at the 3-position of pyrrole and the 2-position of indole or (entries 8, 9 and 14 in Table 5) although they are not the most favorable positions for the electrophilic substitution.

\section{Intramolecular Reactions for the Synthesis of Couma- rins, Quinolinones and a Thiocoumarin}

\subsection{Synthesis of Coumarins}

Initially, we investigated the cyclization of $4^{\prime}-$ tert-butylphenyl phenylpropiolate to screen the catalytic systems, and the results are given in Table $6{ }^{5 \mathrm{c}}$ Treatment of $4^{\prime}-$ tert-butylphenyl phenylpropiolate in the presence of $1 \mathrm{~mol} \%$ $\mathrm{Pd}(\mathrm{OAc})_{2}$ and trifluoroacetic acid as solvent gave cleanly 4-phenyl-6-tert-butylcoumarin as the sole product within 30 min in $90 \%$ yield (entry 2 in Table 6 ). Analysis of the reaction mixture using ${ }^{1} \mathrm{H}$ NMR, ${ }^{13} \mathrm{C}$ NMR spectra and $\mathrm{GC}$ revealed no side reaction. Several transition metals such as $\mathrm{Pd}(\mathrm{II}), \mathrm{Pt}(\mathrm{II}), \mathrm{Rh}$ (II) and $\mathrm{Ni}(\mathrm{II})$ compounds were selected as catalysts for this reaction. The results are summarized in Table 6. Pd catalysts were found to be the most active in the reaction (entries 2 and 5 in Table 6). The reaction with $\mathrm{Pt}$ (II), Ni (II) or Rh(II) catalysts is slow and does not complete within $24 \mathrm{~h}$ (entries 6-8 in Table 6). The catalytic activity of these transition metals decreases in the order $\mathrm{Pd}$ (II) $>\mathrm{Pt}$ (II) $>\mathrm{Ni}(\mathrm{II})>\mathrm{Rh}$ (II) (entries 2,3, and 6-8 in Table 6), in accordance with the activity difference in electrophilic metalation of aromatic $\mathrm{C}-\mathrm{H}$ bonds by these metal ions. ${ }^{2 \mathrm{a}}$ The reaction is greatly enhanced by increasing the quantity of $\mathrm{Pd}(\mathrm{OAc})_{2}$ (entries 2 and 3 in Table 6). Almost no reaction was observed in the absence of either a transition metal catalyst or TFA(entries 1,9 and 10 in Table 6).

Various aryl alkynoates undergo smoothly the intramolecular hydroarylation reactions in the catalytic system $\mathrm{Pd}$ $(\mathrm{OAc})_{2} /$ TFA. The representative examples in Table 7 illustrate the generality of this reaction. ${ }^{5 \mathrm{c}}$ In all cases, the cyclization is highly regioselective, affording kinetically favored 6-membered rings. ${ }^{8}$ Analysis of the crude reaction mixture using ${ }^{1} \mathrm{H}$ NMR, ${ }^{13} \mathrm{C}$ NMR spectra and GC separation indicated no other regioisomers were observed. The reaction exhibits high chemoselectivity with $\mathrm{Br}, \mathrm{CHO}$, or heterocyclic groups in the aromatic moiety(entries 7, 14 and 15 in Table 7) and with either terminal or internal $\mathrm{C}-\mathrm{C}$ triple bonds (entries 4 and 3 in Table 7), which all proved to be compatible. Most of the reactions (monitored by ${ }^{1} \mathrm{H}$ NMR spectrum) are very fast and complete within less than $30 \mathrm{~min}$, especially for those substrates bearing electron-rich aromatic rings (entries 1-8 and 15 in Table 7), showing the characteristics of electrophilic substitutions. Moreover, the reactivity of $2^{\prime}-$, $3^{\prime}-$, and $4^{\prime}$-methylphenyl phenylpropiolates decreases in the order: $3^{\prime}>2^{\prime}>4^{\prime}$ (entries 9,10 and 11 in Table 7), revealing the same characteristics in electrophilic substitutions. The slow cyclization reaction of $4^{\prime}$-methylphenyl phenylpropiolates can be improved by adding more catalyst $(5 \%)$ to the reaction mixture (entries 11 and 12 in Table 7). 
Table 6. Transition-metal catalyzed cyclization of $4^{\prime}$-tertbutylphenyl phenylpropiolate to 4-phenyl-6-tertbutylcoumarin

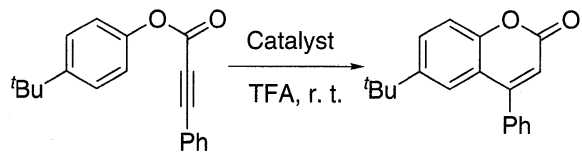

\begin{tabular}{llcl}
\hline Entry Catalyst $(\mathrm{mol} \%)$ & Time $(\mathrm{h})$ Yield $^{a}$ \\
\hline 1 & $\mathrm{None}$ & 24 & 0 \\
2 & $\mathrm{Pd}(\mathrm{OAC})_{2},(1 \%)$ & 0.5 & 90 \\
3 & $\mathrm{Pd}(\mathrm{OAc})_{2},(0.06 \%)$ & 60 & 32 \\
4 & $\mathrm{Pd}\left(\mathrm{O}_{2} \mathrm{CCF}_{3}\right)_{2}\left(\mathrm{PPh}_{3}\right)_{2},(1 \%)$ & 0.5 & 92 \\
5 & $\mathrm{Pd}_{\left(\mathrm{PPh}_{3}\right)_{4}(1 \%)}$ & 1 & 90 \\
6 & $\mathrm{PtCl}_{2}(2 \%)+\mathrm{AgOAC}(4 \%)$ & 24 & 46 \\
7 & $\mathrm{Ni}(\mathrm{OAC})_{2} \quad(2 \%)$ & 24 & 41 \\
8 & $\mathrm{Rh}_{2}(\mathrm{OAc})_{4}(2 \%)$ & 24 & 30 \\
9 & $\mathrm{Pd}(\mathrm{OAc})_{2}(1 \%)+\mathrm{NaO}_{2} \mathrm{CCF}_{3}(5 \%)$ & 24 & Trace $^{b}$ \\
10 & $\mathrm{Pd}\left(\mathrm{O}_{2} \mathrm{CCF}_{3}\right)_{2}\left(\mathrm{PPh}_{3}\right)_{2}(1 \%)$ & 24 & Trace $^{b}$ \\
\hline
\end{tabular}

a $\mathrm{GC}$ yield with diethyl phthalate as internal standard

$b$ Acetic acid $(2 \mathrm{~mL})$ employed as solvent instead of TFA.

\subsection{Synthesis of Quinolinones and a Thiocoumarin}

The extension of this intramolecular addition to the synthesis of N, S-containing heterocycles, 2(1H)-quinolinones and a thiocoumarin, has been made possible with the same catalytic system (entries $1-9$ and 10 in Table 8$){ }^{5 \mathrm{c}}$ The alkynanilides prepared from the corresponding alkynoic acid and anilines are readily cyclized in the presence of $2-3 \mathrm{~mol} \% \mathrm{Pd}$ $(\mathrm{OAc})_{2}$ in a mixed solvent containing TFA at room temperature, giving $2(1 H)$-quinolinones in good yields.

On the other hand, the intermolecular reaction of alkynoic acids and anilines did not afford 2(1H)-quinolinones, presumably because the amino groups in anilines are converted in TFA to ammonium ions which act as electron-withdrawing groups and consequently deactivate the aromatic rings (Scheme 4). Therefore, the intramolecular process offers a unique and efficient method for the synthesis of 2 (1H)-quinolinones.

\section{Reaction Mechanism}

Isotope experiments reveal that D-atoms were incorporated to the vinyl position of adducts either in inter-(Eq. 1 in

Table 7. Synthesis of coumarins via Pd-catalyzed intramolecular hydroarylation reactions from various aryl alkynoates

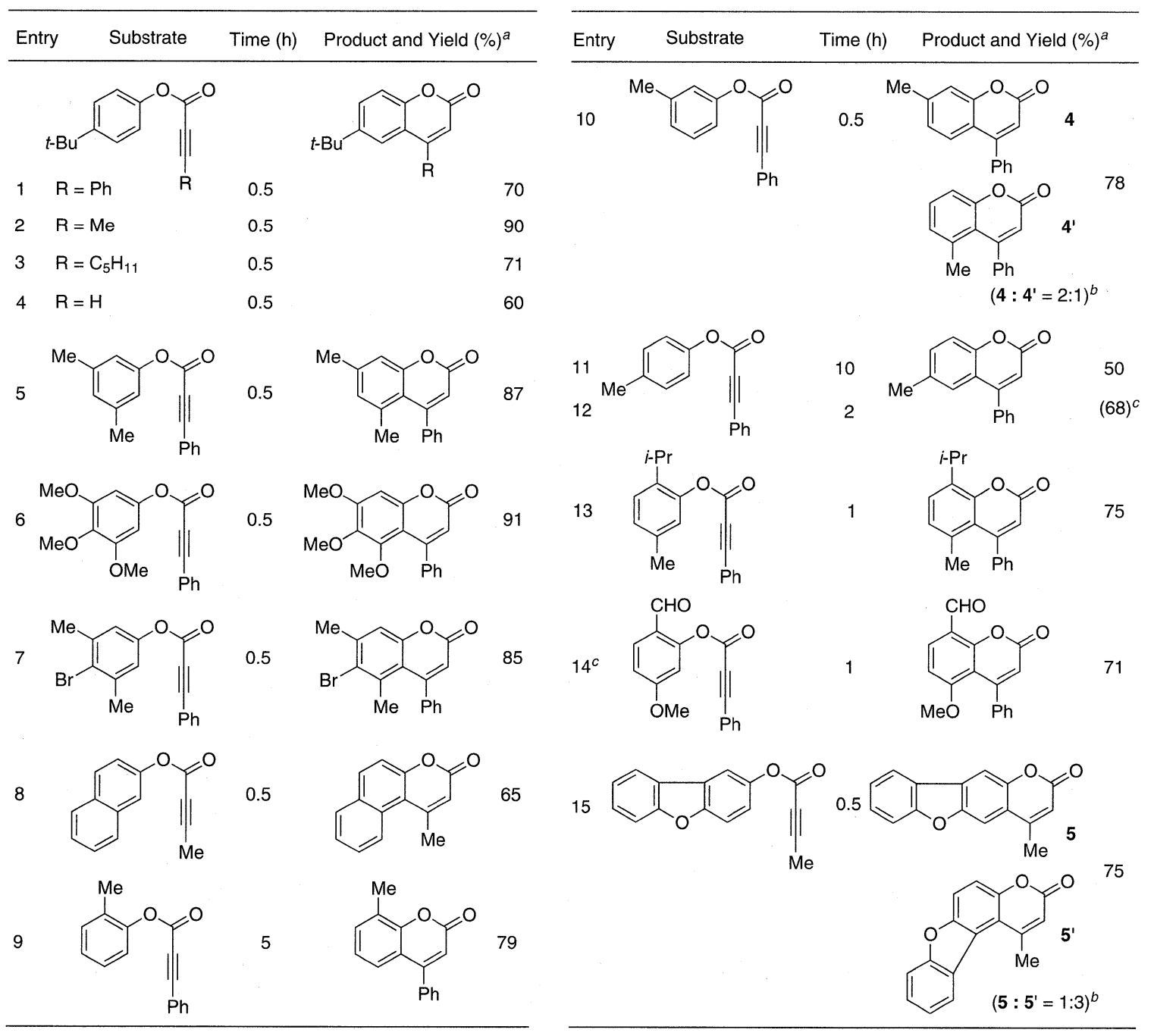

a Isolated yields following the general procedure $\left(1 \% \mathrm{Pd}(\mathrm{OAc})_{2}\right.$ and $1 \mathrm{mmol}$ substrate in $\mathrm{TFA} \mathrm{CH}_{2} \mathrm{Cl}_{2}(1.5 \mathrm{~mL} / 0.5 \mathrm{~mL}$ at r.t. $) \quad b \quad$ The ratio was determined by ${ }^{1} \mathrm{H}$ NMR spectra. ${ }^{c} 5 \% \mathrm{Pd}(\mathrm{OAc})_{2}$, the yield was determined by ${ }^{1} \mathrm{H} \mathrm{NMR}$. 
Table 8. Synthesis of quinoliones and a thiocoumarin via Pd-catalyzed intramolecular hydroarylation

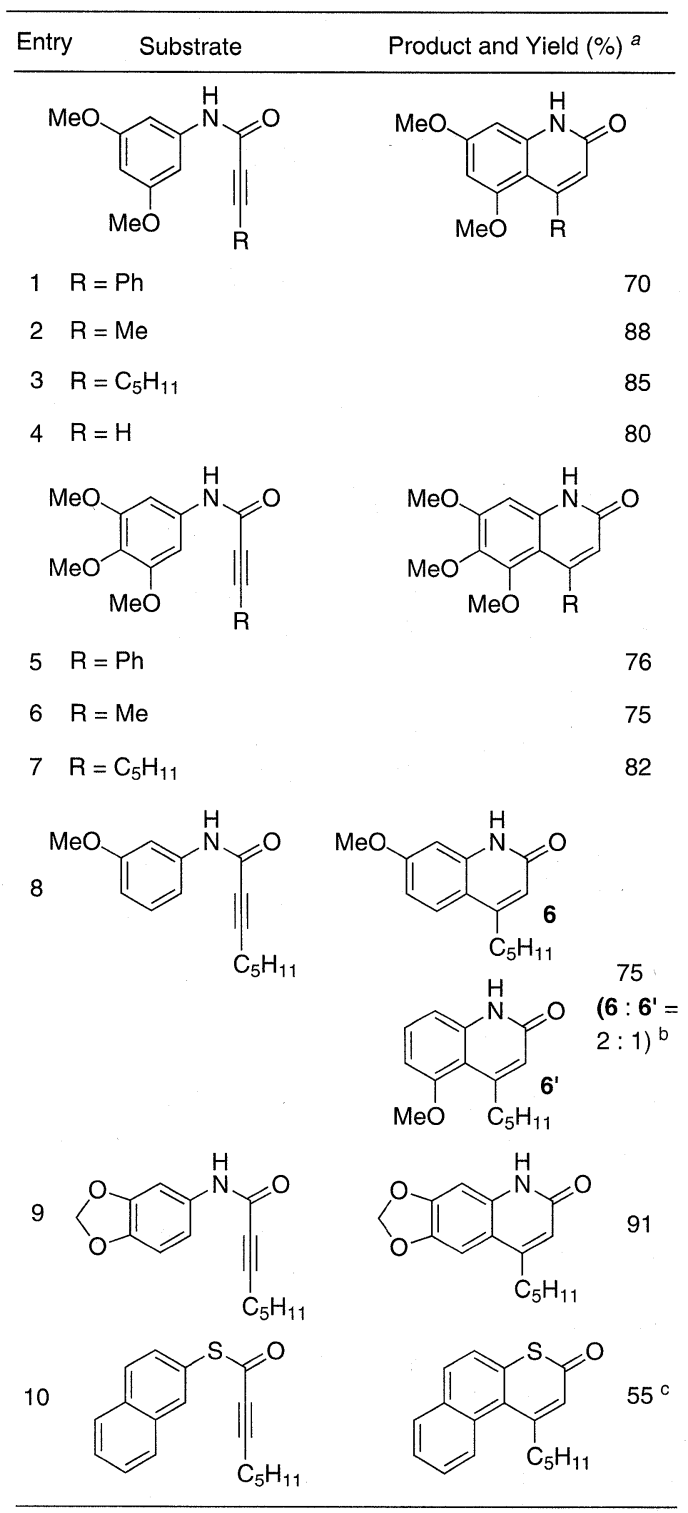

${ }^{a}$ Isolated yields following the general procedure (2-3\% $\mathrm{Pd}(\mathrm{OAc})_{2}$ and $1 \mathrm{mmol}$ substrate in TFA $/ \mathrm{CH}_{2} \mathrm{Cl}_{2}(1.5 \mathrm{~mL} /$ $0.5 \mathrm{~mL}$ at r.t. for $2-5 \mathrm{~h}$ ) ${ }^{\mathrm{b}}$ The ratio was determined by ${ }^{1} \mathrm{H}$ NMR spectra. ${ }^{\circ} 5 \% \mathrm{Pd}(\mathrm{OAc})_{2}, 55 \mathrm{~h}$.

Scheme 5) or intramolecular reactions when the reaction was run in $d$-TFA. ${ }^{5 b, c}$ The reactions of heteroarenes with alkynoates in AcOD gave similar results. ${ }^{5 \mathrm{~d}}$ Also, addition of heteroaromatic C-D bonds to the C-C triple bonds (Eq. 2 in Scheme 5) and the large isotope effect $\left(k_{\mathrm{H}} / k_{\mathrm{D}}=3\right)$ between pyrrole and $d_{5}$-pyrrole in the reaction with ethyl phenylpropiolate have been observed. ${ }^{5 \mathrm{~d}}$

Thus, a possible mechanism involving $\sigma$-aryl-Pd complexes(7) similar to those involved in the coupling of arenes with olefins has been suggested [route(a) in Scheme 6]. ${ }^{3 c}$

Similar $\operatorname{aryl}-\operatorname{Pt}($ II ) complexes have been synthesized from cationic $\mathrm{Pt}$ (II ) complexes. ${ }^{9 \mathrm{a}, \mathrm{b}}$ The facile formation of such $\mathrm{Pd}$-aryl complexes from $\mathrm{Pd}$ (II) and arenes in TFA has been indicated by the coupling reaction of arenes with arenes, ${ }^{9 c, d}$ and also demonstrated by formation of aromatic acid from simple arenes with carbon monoxide(Scheme 1$),{ }^{10}$ and both
Scheme 4. Synthesis of quinoliones

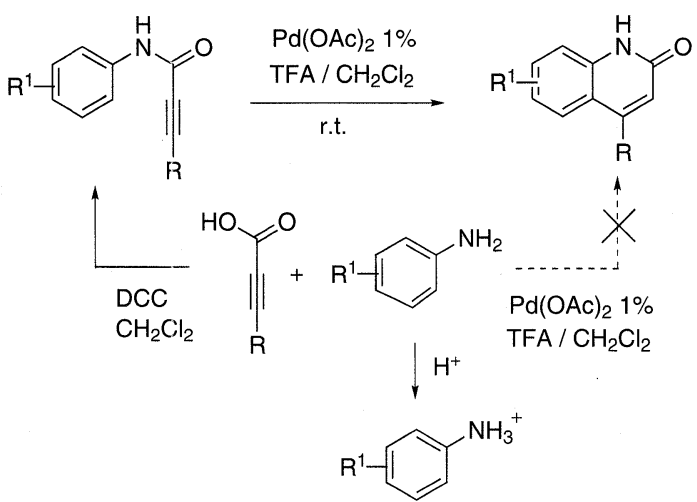

Scheme 5. The selected isotope reactions

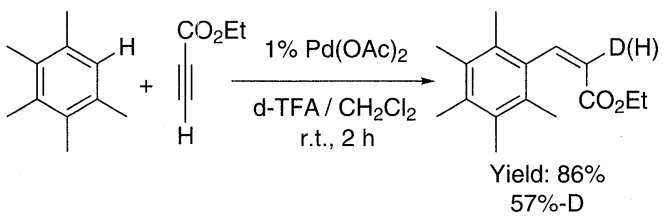

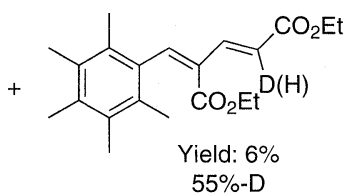

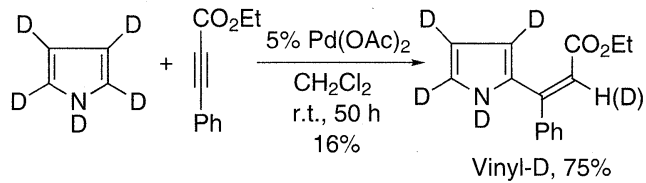

at room temperature. Although the trans-insertion of aryl$\mathrm{Pd}$ complexes to $\mathrm{C}-\mathrm{C}$ triple bonds is not well understood, similar trans-insertion has been reported in several reactions of alkynes, ${ }^{11,12}$ including photo-induced trans-hydrophenylation of alkynes by benzene with a Rh catalyst. ${ }^{11}$. The formation of vinyl-Pd complexes(9) has been suggested by the formation of adducts of two alkynes and one arene(Scheme 7).

The use of TFA as solvent facilitates the generation of a highly cationic $\left[\mathrm{Pd} \text { ( II ) } \mathrm{O}_{2} \mathrm{CCF}_{3}\right]^{+}$species to form $\sigma$-aryl$\mathrm{Pd}$ complexes through electrophilic substitution of aromatic $\mathrm{C}-\mathrm{H}$ bonds. On the other hand, the involvement of a vinyl cationic species (such as 8 , route b in Scheme 5 ) in the reaction cannot be ruled out. ${ }^{5 b, c, 7 b, 13}$ In this context, we have found that the reaction of 3-butyn-2-one with mesitylene can occur without $\mathrm{Pd}(\mathrm{OAc})_{2}$ (Scheme 8$)$, clearly indicating the involvement of a vinyl cationic species generated from alkynes and $\mathrm{H}^{+}$in this reaction. The yield difference in the presence and absence of $\mathrm{Pd}(\mathrm{OAc})_{2}$ may be explained by the competition between $\left[\mathrm{Pd}(\mathrm{II}) \mathrm{O}_{2} \mathrm{CCF}_{3}\right]^{+}$and the vinyl cationic species in electrophilic substitution of aromatic $\mathrm{C}-\mathrm{H}$ bonds. 
Scheme 6. The possible mechanism for inter-and intramolecular hydroarylations

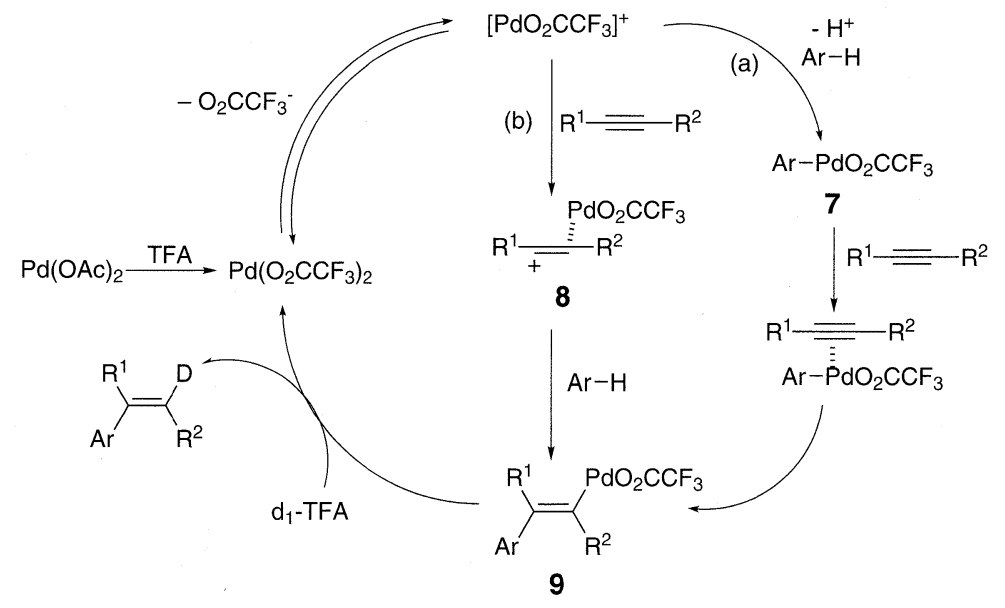

Scheme 7. Formation of the adduct of two alkynes and one arene

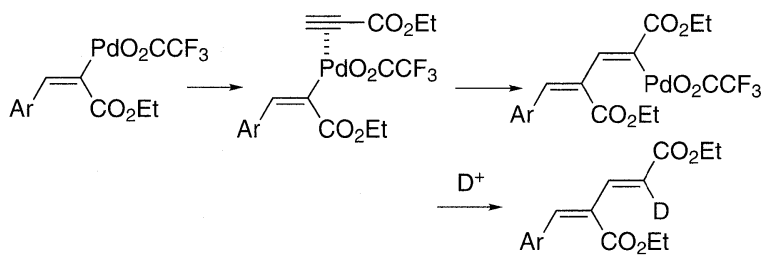

Scheme 8. The reaction of mesitylene with 3-butyn-2-one

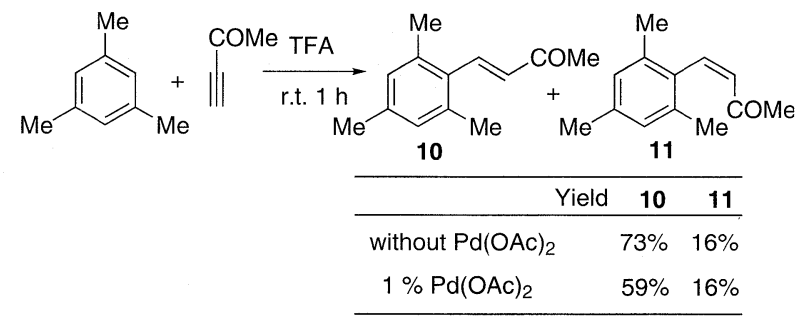

\section{Conclusion}

We have found a very useful addition reaction for direct functionalization of arenes and heteroarenes. The intramolecular reactions have been used to synthesize biologically important heterocycles. Further extension of the reaction to synthesis of functionalized materials is under way.

\section{References}

$\uparrow$ Present Address: Henkel Research Center of Advanced Technology, Molecular Engineering Institute, Kinki University, 11-6 Kayanomori, Iizuka 820-8555, Japan.

1) Trost, B. M. Angew. Chem. Int. Ed. 1995, 34, 259.

2) (a) Shilov, E.; Shul pin, G. B. Chem. Rev. 1997, 97, 2879. (b) Kakiuchi, F.; Murai, S. Activation of Unreactive Bonds and Organic Synthesis (Ed. Murai, S.), Springer, 1999, pp. 47-79. (c)
Dyker, G. Angew. Chem. Int. Ed. 1999, 38, 1698. (d) Chen, H.; Schlecht, S.; Semple, T. C.; Hartwig, J. F. Science, 2000, 287, 1995. (e) Fujiwara, Y. ; Takaki, K.; Taniguchi, Y. Synlett. 1996, 591.

3) (a) Moritani, I.; Fujiwara, Y. Tetrahedron Lett. 1967, 1119. (b) Fujiwara, Y.; Moritani, I.; Danno, S.; Teranishi, S. J. Am. Chem. Soc. 1969, 91, 7166. (c) Fuchita, Y.; Hiraki, K.; Kamogawa, Y.; Suenaga, M.; Toggoh, K.; Fujiwara, Y. Bull. Chem. Soc. Jpn. 1989, 62, 1081.

4) (a) Beletskaya, I. P.; Cheprakov, A. V. Chem. Rev. 2000, 100, 3009. (b) Littke, A. F.; Dai, C.; Fu, G. C. J. Am. Chem. Soc. 2000, 122,4020

5) (a) Jia, C.; Piao, D.; Oyamada, J.; Lu, W.; Kitamura, T.; Fujiwara, Y. Science, 2000, 287, 1992. (b) Jia, C.; Lu, W.; Oyamada, J.; Kitamura, T.; Matsuda, K.; Irie, M.; Fujiwara, Y. $J$. Am. Chem. Soc. 2000, 122, 7252. (c) C. Jia, C.; Piao, D.; Kitamura, T.; Fujiwara, Y. J. Org. Chem. 2000, 65, 7516. (d) Lu, W.; Jia, C.; Kitamura, T.; Fujiwara, Y. Org. Lett., 2000, 2, 2927.

6) (a) Tao, W.; Nesbitt, S.; Heck, R. F. J. Org. Chem. 1990, 55, 66. (b) Tsuji, J. Palladium Reagents and Catalysts, John Wiley \& Sons, 1995

7) (a) Lu, X.; Zhu, G.; Ma, S. Tetrahedron Lett. 1992, 33, 7205. (b) Simonetta, M.; Gavezzotti, A. The chemistry of the Carbon-Carbon Triple Bond (Patai, S. Ed.), John Wiley \& Sons, 1978, part 1, pp. 1-73.

8) Baldwin, J. E. J. Chem. Soc. Chem. Commun. 1976, 734.

9) (a) Brainard, M. W.; Nutt, W. R.; Lee, T. R.; Whitesides, G. M. Organometallics, 1988, 7, 2379. (b) Peters, R. G.; White, S.; Roddick, D. M. Organometallics, 1998, 17, 4493. (c) Clark, F. R. S.; Norman, R. O. C.; Thomas, C. B.; Willson, J. S. J. Chem. Soc. Perkin I, 1973, 1289. (d) Nakajima, R.; Hara, T. Chem. Lett. 1972, 523.

10) (a) Taniguchi, Y.; Yamaoka, Y.; Nakata, K.; Takaki, K.; Fujiwara, Y. Chem. Lett. 1995, 345. (b) Lu, W.; Yamaoka, Y.; Taniguchi, Y.; Kitamura, T.; Fujiwara, Y. J. Organomet. Chem. 1999, 580, 290.

11) Boese, W. T.; Goldman, A. S. Organometallics, 1991, 10, 782.

12) (a) Zeijden, A.; Bosch, H. W; Berke, H. Organometallics, 1992, 11, 563. (b) Zargarrian,D.; Alper, H. Organometallics, 1993, 12, 712. (c) Cacchi, S.; Fabrizi, B.; Marinelli, F.; Moro, L.; Pace, P. Tetrahedron, 1996, 52, 10225. (d) Yanagihara, N.; Lambert, C.; Iritani, K.; Utimoto, K.; Nozaki, H. J. Am. Chem. Soc. 1986, 108, 2753

13) Coldfinger, M. B.; Crawfod, K. B. ; Swager, T. M. J. Am. Chem. Soc. 1997, 119, 4578 . 


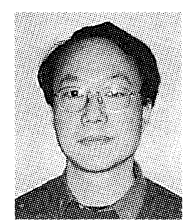

Chengguo Jia obtained his $\mathrm{Ph}$. D. in 1993 from Institute of Chemistry, Chinese Academy of Sciences (Beijing, China) under the guidance of Prof. Y. Y Jiang. After postdoctoral studies with Prof. H. Mimoun and P. Mueller at University of Geneva (Switzerland) during 1993-1995 and with Prof. R. C. Larock at Iowa State University (USA) during 1995-1996, he was employed as senior research engineer by Research Institute of Petroleum Processing, China Petrochemical Co (Sinopec.) in 1996. Since 1998, he has been working on Pd-catalyzed synthetic reactions with Prof. Y. Fujiwara in Kyushu University as a research fellow of Japan Society for the Promotion of Science. His research interests cover polymer-supported synthesis and catalysts, zeolite catalysts and transition-metal catalyzed organic synthesis.

Tsugio Kitamura received his $\mathrm{Ph} . \mathrm{D}$ from Kyushu University in 1982 under the direction of Prof. H. Taniguchi. He joined the faculty as an assistant professor at Kyushu University in 1982. Since 1993 he has been an associate professor at Kyushu University. In 1986-1988 he worked as a postdoctoral fellow with Prof. P. J. Stang at University of Utah,

U.S.A. His research interests involved mechanistic and synthetic chemistries on vinyl cations. His current interests are in the field of chemistry of hypervalent main group elements (iodine and sulfur) and transition metals such as palladium.
Yuzo Fujiwara received his $\mathrm{Ph}$. D. from Osaka University under the supervision of Prof. I. Moritani in 1969. He worked as NSF postdoctoral fellow with Prof. G. M. Whitesides in MIT, USA from 1972 to 1974 . After working as an assistant professor in Osaka University, he was promoted to associate professor in Kyushu University in 1977, and full professor in Hiroshima University in 1988. Professor Fujiwara moved to Kyushu University in 1995, and retired in 2001. $\mathrm{He}$ is now a visiting professor of the Molecular Engineering Institute, Kinki University. Professor Fujiwara has very broad research interests in developing new synthetic reactions based on the chemistry of both d-and f-block transition metals, especially palladium and rare earth metals. He has been the recipient of several scientific awards, including Japan Rare Earth Society Awards in 1992 and Chemical Society of Japan Award in 2000. 